\title{
Protective Effect of Rhizophora mucronata Leaves on Hepatic Oxidative Stress, Serum Cytokines and Insulin Resistance in Type 2 Diabetic Rats
}

\author{
Moumita Ray ${ }^{1}$, Rania Indu², Sangita Bhattacharya ${ }^{2}$, Anjan Adhikarij, \\ 1Department of Pharmaceutical Technology, JIS University, Agarpara, Kolkata, West Bengal, INDIA. \\ 2Department of Pharmacology, RG Kar Medical College, Kolkata, West Bengal, INDIA. \\ ${ }^{3}$ Department of Pharmacology, Coochbehar Government Medical College, Coochbehar, West Bengal, INDIA.
}

\begin{abstract}
Aim: Glucose homeostasis is mainly controlled by liver, which is altered in diabetes. Metabolic alteration and insulin resistance develop due to oxidative stress and inflammation. Plant secondary metabolites have therapeutic relevance in diabetes and associated complications. Present study evaluated the effect of hydro-alcoholic extract of Rhizophora mucronata leaves (RME) in diabetes induced hepatic oxidative stress, serum cytokines and insulin resistance in Streptozotocin-Nicotinamide induced type 2 diabetic rats. Materials and Methods: The diabetic rats were treated with extract for 28 days and liver markers as well tissue antioxidant parameters (nitric oxide, reduced glutathione, superoxide dismutase), lipid peroxide contents and histology of liver were studied. Serum insulin, C-peptide were estimated and insulin resistance parameters were evaluated using homeostasis model assessment (HOMA). Serum cytokines like tumour necrosis factor- $\alpha$ (TNF- $\alpha$ ), interleukin-6 (IL-6) and interleukin-1 $\beta$ (IL-1 $\beta$ ) were analyzed. Results: Rhizophora mucronata leaves extract decreased the elevated hepatic enzymes, restored the hepatocellular damages by reducing the lipid peroxides and free radicals near normal, as well as inducing the cellular antioxidants. Correlation analysis of insulin resistance with the cytokines revealed significant positive association with TNF- $\alpha$ $(r=0.662, p<0.01)$. RME in both $200 \mathrm{mg} / \mathrm{kg}$ and $400 \mathrm{mg} / \mathrm{kg}$ doses reduced the serum pro-inflammatory cytokines and also inhibited HOMA-IR potentially by $72 \%$ than the untreated diabetic control rats. Conclusion: Present study indicated the hepatoprotective effect of Rhizophora mucronata leaves against diabetes induced damage, could maintain normal glucose homeostasis. Anti-diabetic action of this mangrove plant might be mediated through significant antioxidant action with reduction of inflammatory cytokines as well as amelioration of insulin resistance.
\end{abstract}

Key words: Antioxidant, Cytokines, Hepatoprotective, Insulin resistance, Rhizophora mucronata.

\section{INTRODUCTION}

In healthy individuals, glucose homeostasis in the body is mainly controlled by liver. ${ }^{1}$ In the post-prandial state the dietary carbohydrates, absorbed from intestine is utilized by the hepatocytes through a number of metabolic pathways. Hepatocytes play a pivotal role in glucose metabolism. It has been estimated that $30 \%$ - 60\% of all absorbed glucose in the body either metabolised into amino acids, fatty acids or subsequently stored as glycogen in the liver. On the other hand, in fasting condition liver also plays a crucial role by releasing glucose to the systemic circulation either by breakdown of stored glycogen (glycogenolysis) or by producing glucose (gluconeogenesis). ${ }^{1}$ Insulin is a key hormone which enhances the conversion of glucose to glycogen within the liver and inhibits glucose production. ${ }^{2}$
Submission Date: 16-03-2020; Revision Date: 08-06-2020; Accepted Date: 13-08-2020

DOI: 10.5530/ijper.54.3s.155 Correspondence: Dr. Anjan Adhikari Professor and Head, Coochbehar Government Medical College,

Coochbehar-736101, West Bengal, INDIA.

Phone: +919831012503

E-mail: iacsm.rgkmc@gmail. com

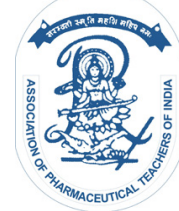

www.ijper.org 
In diabetic state, hepatocytes failed to respond to the insulin action and glucose homeostasis gets hampered by uncontrolled glycogenolysis, gluconeogenesis. These, in turn, develop hyperglycemia, dyslipidemia and systemic insulin resistance. There is growing evidence that oxidative stress and inflammation are interrelated and play an important role in metabolic alteration and progression of insulin resistance, which, in turn, develop type 2 diabetes mellitus (T2DM). ${ }^{3,4}$ Imbalance between cellular antioxidants and reactive oxygen species level results in oxidative stress in the body, eventually causing cellular apoptosis. This induces the release of inflammatory cytokines like tumour necrosis factoralpha (TNF- $\alpha$ ), interleukin-6 (IL-6), interleukin-1beta (IL-1 $\beta$ ) and leucocyte infiltration. ${ }^{5}$ These inflammatory signals inhibit insulin signalling pathway and gradually develop insulin resistance.

The secondary metabolites of the plants, mainly flavonoids, tannin, polyphenols act as potent antioxidant by preventing free radical generation due to diabetes, protect $\beta$ cell function and thus have beneficial effect against diabetes and its related complications. ${ }^{6}$ Mangrove plants are considered as a rich source of these bioactive phytoconstituents. Rhizophora mucronata is a medicinal mangrove plant diversely found in the mangrove region and widely used as therapeutic agent for treating different ailments. ${ }^{7}$ Hydro-alcoholic extract of Rhizophora mucronata leaves possesses significant antioxidant potential, anti-hyperglycemic activity and also controls lipid impairment. ${ }^{8,9}$ Research suggests that the mangrove plant also promotes protection against gastric damage by modulating cellular antioxidants and inhibiting lipid peroxide production. ${ }^{10}$ Therefore, the present study aimed to evaluate whether the hydroalcoholic extract of Rhizophora mucronata leaves reduces diabetes-induced hepatic oxidative stress, serum cytokines and insulin resistance in StreptozotocinNicotinamide induced rats, a non-obese model of experimental T2DM.

\section{MATERIALS AND METHODS}

\section{Collection, identification and preparation of extract}

The mangrove leaves were collected from Sunderban, West Bengal, India and were authenticated from Botanical Survey of India, Howrah, West Bengal (CNH/55/2013/Tech.II/19 dated 02.12.2013) as Rhizophora mucronata Lam. The leaves were shade-dried, powdered and extracted with hydro-ethanol (50\%) in soxhlet apparatus. Thereafter, the solvent was removed under reduced pressure and the extract was dried. The hydro-alcoholic extract of Rhizophora mucronata leaves was designated as RME.

\section{Animals}

Wistar albino rats both male and female, 150-200g body weight were used for this study. The animals were kept in the Institutional animal house, maintaining proper condition, diet and water ad libitum. The animal experiments were conducted in accordance with the accepted principles for laboratory animal use and care by Committee for the Purpose of Control and Supervision of Experiments on Animals (CPCSEA) and the study was approved by the Institutional Animal Ethics Committee, R. G. Kar Medical College, Kolkata.

\section{Induction of non-insulin dependent type 2 diabetes}

Type 2 diabetes mellitus was developed in adult Wistar rats with Streptozotocin-Nicotinamide (STZ-NA) induced diabetic model. ${ }^{11}$ The rats were fasted overnight and nicotinamide $(110 \mathrm{mg} / \mathrm{kg}$ body weight for each rat, dissolved in normal saline) was administrated intraperitonealy. After $15 \mathrm{~min}$ intravenous injection of STZ $(60 \mathrm{mg} / \mathrm{kg}$ body weight for each rat dissolved in citrate buffer, $\mathrm{pH} 4.5$ ) was given to the rats.

\section{Experimental design}

Type 2 diabetes was induced with STZ and NA and $72 \mathrm{hrs}$ after induction, diabetes was confirmed with estimation of blood glucose. The rats with blood glucose level $>250 \mathrm{mg} / \mathrm{dl}$ were considered as diabetic and included in the study. ${ }^{11,12}$ The diabetic rats were then randomly selected and divided into six groups. The doses of the standard drug Glibenclamide and RME extract treated groups were standardized as per previous anti-diabetic efficacy study with this extract. ${ }^{8,9}$ The group division ( $n=6$ in each group) was done and treatments were given as follows:

Group I: Normal control (without STZ-NA, distilled water $0.1 \mathrm{ml} / \mathrm{kg}$, orally for 28 days)

Group II: Diabetic control (STZ-NA induced, distilled water $0.1 \mathrm{ml} / \mathrm{kg}$, orally for 28 days)

Group III: Diabetic treated with Glibenclamide (10mg/ $\mathrm{kg}$, orally for 28 days)

Group IV: Diabetic treated with RME $(100 \mathrm{mg} / \mathrm{kg}$, orally for 28 days)

Group V: Diabetic treated with RME $(200 \mathrm{mg} / \mathrm{kg}$, orally for 28 days)

Group VI: Diabetic treated with RME (400mg/kg, orally for 28 days)

After the experimental period of 28 days, blood was collected from each group of rats from the retro-orbital 
plexus and serum was isolated. The liver enzymes such as serum glutamic oxaloacetic transaminase (SGOT), serum glutamic pyruvic transaminase (SGPT) and alkaline phosphatase (ALP) were studied in the serum of all the experimental groups of rats with the commercially available diagnostic kits. Serum insulin, C-peptide, cytokines like tumour necrosis factor- $\alpha$ (TNF- $\alpha$ ), interleukin-1 $\beta$ (IL-1 $\beta$ ) and interleukin-6 (IL-6) were estimated using Enzyme-Linked Immunosorbent Assay (ELISA) method. Nitric oxide (NO), reduced glutathione $(\mathrm{GSH})$ and superoxide dismutase (SOD) activities were estimated in the liver tissues. Extent of oxidative stress was also assessed by determination of hepatic lipid peroxides. A portion of liver was processed for histological evaluation with haematoxylin and eosin ( $\mathrm{H}$ and $\mathrm{E}$ ) staining.

\section{Tissue antioxidant parameters}

For the tissue antioxidant studies, 10\% homogenate of liver was prepared in $0.1 \mathrm{M}$ phosphate buffer and centrifuged for $10 \mathrm{~min}$ at $5000 \mathrm{rpm}$. The supernatant was collected and used for experimental analysis. Amounts of antioxidant activities were calculated with the help of the standard curve plotted with the respective antioxidant standard and the amount of protein present in tissue. Protein contents of the liver tissue were estimated by Lowry method ${ }^{13}$ and different tissue antioxidant parameters like lipid peroxidation (LPO), nitric oxide (NO), reduced glutathione (GSH) contents and superoxide dismutase (SOD) activities were evaluated with the following methods.

\section{Nitric oxide assay ${ }^{14}$}

$100 \mu$ l of $10 \%$ liver homogenate was mixed with $500 \mu \mathrm{l}$ of Griess reagent $(1 \mathrm{~g} / 1$ sulfanilamide $+25 \mathrm{~g} / 1$ phosphoric acid $+0.1 \mathrm{~g} / 1$ N-1-naphthylethylenediamine) and incubated for $30 \mathrm{~min}$ at room temperature. Then the absorbance was measured at $540 \mathrm{~nm}$. Amount of nitric oxide was calculated with the help of the standard curve plotted with sodium nitrite in respect to the amount of protein present in tissue.

\section{Lipid peroxidation assay ${ }^{14,15}$}

$0.5 \mathrm{ml}$ of $10 \%$ tissue homogenate was added to $1 \mathrm{ml}$ of TBARS solution $[0.375 \%$ (wt/vol) thiobarbituric acid $(\mathrm{TBA})+15 \%$ (wt/vol) tri-chloro acetic acid (TCA) prepared in $0.25 \mathrm{~N}$ hydrochloric acid $(\mathrm{HCl})]$. The solution was heated in boiling water for $30 \mathrm{~min}$ and then cooled. It was then centrifuged at $3000 \mathrm{rpm}$ for 15 min. The absorbance of supernatant measured at 532 $\mathrm{nm}$ against blank. Amount of malondialdehyde (MDA) was calculated with standard curve of MDA in respect to the amount of protein present in tissue.

\section{Superoxide dismutase assay ${ }^{14,15}$}

$1.2 \mathrm{ml}$ of sodium pyrophosphate buffer $(0.052 \mathrm{mM}$; $\mathrm{pH}$ 8.3), $0.1 \mathrm{ml}$ of $186 \mu \mathrm{M}$ phenazine methosulphate (PMS), $0.2 \mathrm{ml}$ of $10 \%$ liver homogenate and $1 \mathrm{ml}$ distilled water were added to each reaction mixture. Thereafter $0.3 \mathrm{ml}$ of $300 \mu \mathrm{M}$ nitroblue tetrazolium (NBT) and $0.2 \mathrm{ml}$ of nicotinamide adenine dinucleotide reduced i.e. $\mathrm{NADH}$ $(780 \mu \mathrm{M})$ was added to start the reaction. The reaction was incubated in dark at room temperature for 90 seconds and was stopped by adding $1 \mathrm{ml}$ of glacial acetic acid. The amount of chromogen formed was measured at $560 \mathrm{~nm}$. Amount of superoxide dismutase (SOD) was calculated with the SOD standard curve and the amount of protein present in tissue.

\section{Reduced glutathione level ${ }^{14}$}

$100 \mu \mathrm{l}$ of $10 \%$ liver homogenate was dissolved in $600 \mu \mathrm{l}$ of ethylene di-amine tetra acetic acid (EDTA) and incubated in ice for $10 \mathrm{mins} .500 \mu \mathrm{l}$ water, $250 \mu \mathrm{l}$ tricholoro acetic acid $(10 \% \mathrm{wt} / \mathrm{vol})$ were added and incubated at room temperature for 5 mins. It was then centrifuged at $5000 \mathrm{rpm}$ for $10 \mathrm{~min}$. $2 \mathrm{ml}$ of Tris [Tris(hydroxymethyl)aminomethane] buffer $(0.4 \mathrm{M})$ and $100 \mu$ of DTNB or Ellman's Reagent (5,5'-dithio-bis[2-nitrobenzoic acid]) (0.1M) was added to $1 \mathrm{ml}$ of the supernatant and incubated at room temperature for $3 \mathrm{~min}$. Absorbance was measured at $412 \mathrm{~nm}$. The reduced chromogen is directly proportional to GSH concentration. Amount of reduced glutathione was calculated with the glutathione reduced (GSH) standard curve and the amount of protein present in tissue.

\section{Measurement of serum insulin and related parameters}

Serum insulin and C-peptide levels were evaluated using rat ELISA kit and some insulin related parameters were also calculated using mathematical tool homeostasis model assessment (HOMA). ${ }^{12,16}$ Some of these parameters like HOMA model for insulin resistance (HOMA-IR), quantitative insulin sensitivity check index (QUICKI) were calculated by the following formula-

HOMA-IR: fasting blood glucose $(\mathrm{mg} / \mathrm{dl}) \times$ insulin $(\mu \mathrm{IU} / \mathrm{ml}) / 405$;

QUICKI: 1 / (log FBS (mg/dl) + log insulin $(\mu \mathrm{IU} / \mathrm{ml}))$

\section{Measurement of serum cytokines}

Serum was isolated from each group of rats after experiment and different inflammatory cytokines like tumour necrosis factor- $\alpha$ (TNF $\alpha$ ), interleukin-1 $\beta$ (IL- 
1及) and interleukin-6 (IL-6) were analyzed using ELISA kits for rats.

\section{Statistical analysis}

All the data were expressed as mean \pm SEM. In the present study statistical analysis was done by one-way ANOVA followed by Dunnet test by using statistical package for the social sciences (SPSS version 20) software.

\section{RESULTS}

Liver damage is the most common in diabetes mellitus. In the present study, serum SGOT, SGPT and alkaline phosphatase levels were very significantly altered in STZ-NA induced diabetic control rats compared with normal control rats.

Figure 1 showed the effect of R. mucronata leaves hydroalcoholic extract on hepatic enzymes in diabetic rats. The liver enzyme levels in the diabetic control rats were found to be elevated significantly indicating severe hepatic damage. Glibenclamide treated group as well as the RME treated groups revealed significant decreased levels compared with diabetic control group. In the present study generation of hepatic oxidative stress in Streptozotocin-Nicotinamide induced type 2 diabetic rats and the effect of the hydroalcoholic extract of Rhizophora mucronata Lam. leaves was evaluated.

Table 1 data showed the extract revealed good antioxidant potential by inhibiting the damages due to the free radical generation in diabetic state. In the STZ-NA induced diabetic control rats, nitric oxide (NO) levels in liver tissue were found to be increased as compared to that of normal control. Glibenclamide and RME in different doses showed a lower level of $\mathrm{NO}$ as compared to the diabetic control group. Lipid peroxidation was biochemically assessed by determining malondialdehyde levels (MDA). MDA levels in liver tissue homogenates were elevated significantly in diabetic control group (approximately 90\%) compared to normal control group. Administration of RME potentially reduced the LPO level significantly at the end of 28 days treatment. Reduced glutathione (GSH) is a cellular endogenous antioxidant, which was significantly decreased in liver tissue homogenate in diabetes. Administration of RME increased the GSH level near normal level at the end of 28 days treatment.

Histological studies of liver tissues of different groups of rats were done and observed under microscope for any structural change.

The liver of normal control rats (Photomicrograph Ia) revealed normal liver histology. The liver section of STZ-NA induced diabetic control rats (Photomicrograph Ib) showed distended, congested central vein and lots of inflammatory cells were present in sinusoids and surrounding portal triad. Lots of pyknotic or necrotic hepatocytes were present. The liver tissue of Glibenclamide $(10 \mathrm{mg} / \mathrm{kg})$ treated rats (Photomicrograph Ic) showed approximately normal architecture though some inflammatory cells were present with dilated central vein, some vacuoles were present. Consecutive treatment with the hydroalcoholic extract of Rhizophora mucronata leaves (RME) in $100 \mathrm{mg} / \mathrm{kg}$ pyknotic hepatocytes were abundant (Photomicrograph Id). $200 \mathrm{mg} / \mathrm{kg}$ and $400 \mathrm{mg} / \mathrm{kg}$ doses revealed dilated central vein, less number of pyknotic cells and inflammations were also reduced (Photomicrograph Ie and If).

The normal control rats showed negligible expression of the inflammatory cytokines, whereas the diabetic rats revealed significant levels of inflammatory cytokines mainly TNF- $\alpha$ and IL-6. Treatment with the hydro-alcoholic extract of Rhizophora mucronata leaves significantly reduced the levels of the pro-inflammatory

\begin{tabular}{|c|c|c|c|c|c|c|}
\hline \multirow[b]{2}{*}{ Parameters } & \multicolumn{6}{|c|}{ Groups } \\
\hline & $\begin{array}{l}\text { Normal } \\
\text { control }\end{array}$ & $\begin{array}{l}\text { Diabetic } \\
\text { control }\end{array}$ & $\begin{array}{l}\text { Glibenclamide } \\
10 \mathrm{mg} / \mathrm{kg}\end{array}$ & $\begin{array}{l}\text { RME 100mg/ } \\
\text { kg }\end{array}$ & $\begin{array}{l}\text { RME 200mg/ } \\
\text { kg }\end{array}$ & $\begin{array}{l}\text { RME } 400 \mathrm{mg} / \\
\text { kg }\end{array}$ \\
\hline $\begin{array}{l}\text { Malondialdehyde ( } \mu \mathrm{M} / \mathrm{mg} \\
\text { protein) }\end{array}$ & $0.017 \pm 0.0002$ & $0.167 \pm 0.0003$ & $0.085 \pm 0.0007$ & $0.038 \pm 0.0005^{*}$ & $0.029 \pm 0.0006^{*}$ & $0.049 \pm 0.003^{*}$ \\
\hline $\begin{array}{l}\text { Nitric oxide (mM/mg } \\
\text { protein) }\end{array}$ & $0.0002 \pm 0$ & $0.007 \pm 0$ & $0.001 \pm 0.002^{*}$ & $0.001 \pm 0.003^{*}$ & $0.0005 \pm 0.003^{*}$ & $0.0005 \pm 0.002^{*}$ \\
\hline $\begin{array}{l}\text { Reduced glutathione (mM/ } \\
\text { mg protein) }\end{array}$ & $0.749 \pm 0.05$ & $0.238 \pm 0$ & $0.53 \pm 0.0005$ & $0.605 \pm 0.005$ & $0.818 \pm 0.001$ & $0.777 \pm 0.002$ \\
\hline $\begin{array}{l}\text { Superoxide dismutase } \\
\text { activity (mM/mg protein) }\end{array}$ & $0.07 \pm 0.001$ & $0.043 \pm 0.001$ & $0.056 \pm 0.006$ & $0.062 \pm 0.006$ & $0.067 \pm 0.006$ & $0.072 \pm 0.001$ \\
\hline
\end{tabular}

Values were represented as Mean $\pm \operatorname{SEM}(n=6)$. Statistical analysis was done using one way ANOVA followed by Dunnet test; *denotes level of significance, $p<0.05$. RMEhydro-alcoholic extract of Rhizophora mucronata leaves. 
cytokines than the diabetic control rats, which were comparable with the normal control animals (Table 2). Fasting insulin and C-peptide levels were determined in the serum of different group of rats. On the basis of the fasting blood glucose and serum insulin level, the insulin-based index like homeostasis model assessment of insulin resistance were calculated.

In this STZ-NA induced non-insulin dependent type 2 diabetic model, the insulin and C-peptide levels in the serum of the diabetic rats were slightly decreased compared to the normal control group. However, regular administration of RME maintained both the serum insulin and C-peptide levels near normal in a dose dependant manner. HOMA-IR is the widely used insulin resistant evaluation index, which increased significantly in the STZ-NA induced diabetic rats. The treatment with RME in both $200 \mathrm{mg} / \mathrm{kg}$ and $400 \mathrm{mg} /$ $\mathrm{kg}$ reduced HOMA-IR potentially by $72 \%$ than the diabetic control rats, which was comparable with the standard drug Glibenclamide. All these parameters were restored near normal in the treated groups at the end of the treatment than the diabetic control rats (Table 3).
A correlation analysis was evaluated among the insulin resistance indices and cytokines measured in the serum of the rats. Correlation analysis of HOMA-IR with the cytokines revealed significant positive correlation with TNF- $\alpha(r=0.662, p<0.01)$. Therefore, from the present study data and correlation analysis (Figure 2), it can be stated that the activation of pro-inflammatory cytokine TNF- $\alpha$ is directly proportional to the development of insulin resistance. In the diabetic control rats the generation of inflammatory cytokines and insulin resistant index were significantly higher than the healthy normal control rats. These elevated parameters were reduced after the treatment with the hydro-alcoholic extract of Rhizophora mucronata leaves.

\section{DISCUSSION}

The onset of diabetes is associated with the biochemical and functional abnormalities mainly in the liver, which is a major reason for the alteration of glucose homeostasis. In the present study, increased serum ALP in the diabetic control rats indicated the damage of the plasma membrane and the transaminase enzymes (SGOT

\begin{tabular}{|c|c|c|c|}
\hline Groups & TNF- $\alpha(\mathrm{pg} / \mathrm{ml})$ & IL-6 (ng/l) & IL-1 $\beta$ (ng/ml) \\
\hline Normal control & $187.17 \pm 6.16$ & $9.21 \pm 1.24$ & $1.42 \pm 0.26$ \\
\hline Diabetic control & $268.17 \pm 7.87$ & $15.81 \pm 1.58$ & $2.2 \pm 0.21$ \\
\hline Glibenclamide $10 \mathrm{mg} / \mathrm{kg}$ & $219.17 \pm 7.06^{*}$ & $10.6 \pm 1.08$ * & $1.76 \pm 0.17$ \\
\hline RME $100 \mathrm{mg} / \mathrm{kg}$ & $242.17 \pm 7.12$ * & $14.13 \pm 1.03$ & $2.04 \pm 0.25$ \\
\hline RME $200 \mathrm{mg} / \mathrm{kg}$ & $210.17 \pm 8.87$ * & $11.28 \pm 1.16$ * & $1.64 \pm 0.36$ * \\
\hline RME $400 \mathrm{mg} / \mathrm{kg}$ & $195.33 \pm 6.13$ * & $10.4 \pm 1.35$ * & $1.48 \pm 0.13$ * \\
\hline
\end{tabular}

Values were represented as Mean \pm SEM. Statistical analysis was done using one way ANOVA followed by Dunnet test; *denotes level of significance, $p<0.05$. RME- hydro-alcoholic extract of Rhizophora mucronata leaves.

\begin{tabular}{|c|c|c|c|c|c|}
\hline Groups & $\begin{array}{l}\text { Fasting blood } \\
\text { glucose (mg/dl) }\end{array}$ & $\begin{array}{c}\text { Insulin }(\mu \mathrm{IU} / \\
\mathrm{ml})\end{array}$ & $\begin{array}{l}\text { C-peptide } \\
\text { (nmol/ml) }\end{array}$ & HOMA-IR & QUICKI \\
\hline Normal control & $91.67 \pm 2.21$ & $42.75 \pm 0.004$ & $2.45 \pm 0.01$ & $9.68 \pm 0.1$ & $0.28 \pm 0.002$ \\
\hline Diabetic control & $433 \pm 2$ & $30 \pm 0.004$ & $2.09 \pm 0.17$ & $32.07 \pm 0.03$ & $0.22 \pm 0.002$ \\
\hline Glibenclamide $10 \mathrm{mg} / \mathrm{kg}$ & $130 \pm 1.92$ * & $32.67 \pm 0.004$ & $2.18 \pm 0.05$ & $10.49 \pm 0.11$ * & $0.28 \pm 0.002$ \\
\hline RME $100 \mathrm{mg} / \mathrm{kg}$ & $111 \pm 1.03$ * & $32.33 \pm 0.003$ & $2.1 \pm 0.03$ & $8.86 \pm 0.11$ * & $0.28 \pm 0.001$ \\
\hline RME $200 \mathrm{mg} / \mathrm{kg}$ & $104.17 \pm 1.15$ * & $35 \pm 0.002$ & $2.32 \pm 0.15$ & $9 \pm 0.11$ * & $0.28 \pm 0.001$ \\
\hline RME $400 \mathrm{mg} / \mathrm{kg}$ & $92.5 \pm 1.33^{*}$ & $38.83 \pm 0.004$ & $2.51 \pm 0.17$ & $8.87 \pm 0.11$ * & $0.28 \pm 0.002$ \\
\hline
\end{tabular}

Values were mean \pm SEM $(n=6)$. Statistical analysis were done using one way ANOVA followed by Dunnet test; *denotes level of significance, $p<0.05$. RME- hydro-alcoholic extract of Rhizophora mucronata leaves, HOMA-IR- homeostatic model assessment of insulin resistance, QUICKI- quantitative insulin sensitivity check index. 


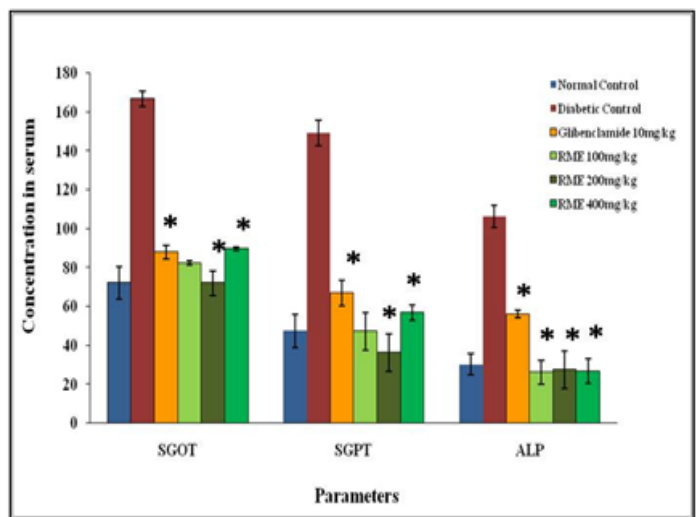

Figure 1: Liver enzymes in rat serum of all groups after 28 days of STZ-NA induced diabetic model.

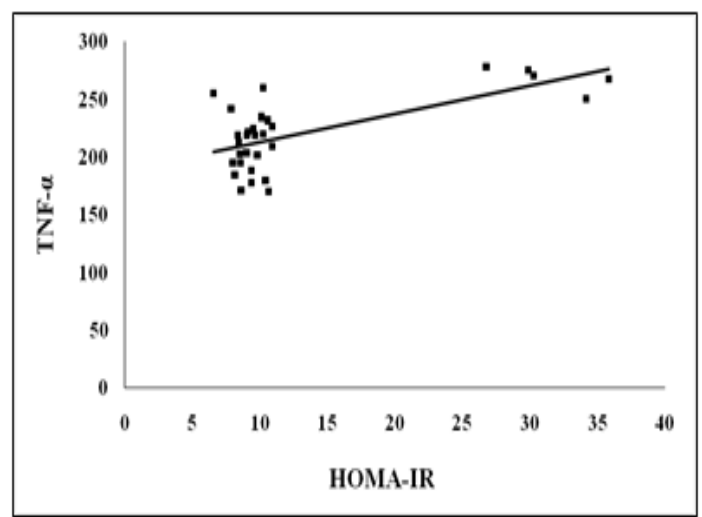

Figure 2: Correlation analysis of HOMA-IR with the serum cytokine TNF-a.

and SGPT) are well-known as biomarkers to assess the hepatotoxicity. ${ }^{17}$ Oral administration of the test extract decreased the elevated hepatic enzyme levels in treated rats than the diabetic control, indicating the beneficial effect of the extract against liver damage due to diabetes. The cellular metabolism in the body is associated with the oxidation of biomolecules and production of reactive oxygen species (ROS) as intermediates. These oxidative by-products when generate in excess amount, induce cellular damage. In type 2 diabetes, development of insulin resistance causes lipolysis, release of free fatty acid in the blood and its accumulation in liver. As well as the adipocytes release adipocytokines like tumour necrosis factor- $\alpha$ and leptin, which increases oxidative stress in the mitochondria and worsen the hepatic damage. Imbalance between oxidants and cellular antioxidants results in oxidative stress, exhibiting a state of chronic low grade inflammation and activation of inflammatory cytokines. Elevated amounts of the proinflammatory cytokines like tumour necrosis factor- $\alpha$ $(\mathrm{TNF}-\alpha)$, interleukin-1 $\beta$ (IL-1 $\beta$ ) and interleukin-6 (IL-6) have been confirmed in diabetes mellitus. This
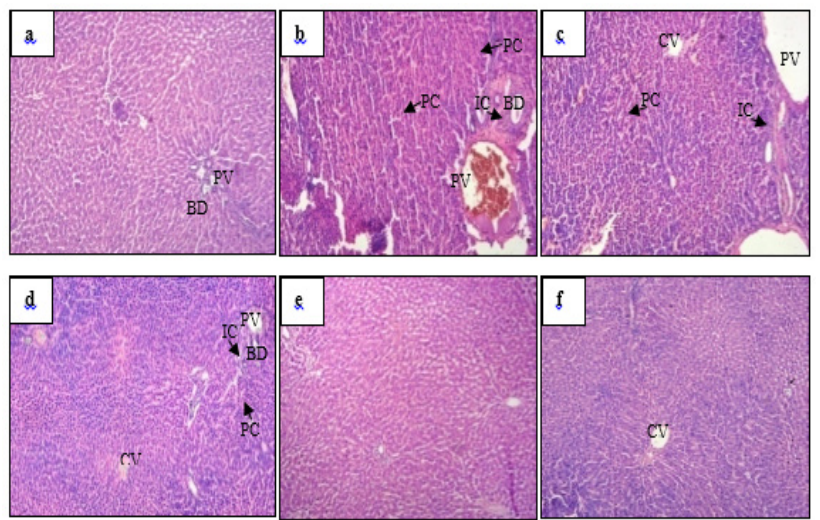

Photomicrograph I: Histological sections of the liver tissues of different groups of rats.

[Magnification 10x, stained by hematoxylin and eosin] PC=Pyknotic cells, $\mathrm{IC}=\mathrm{Inflammatory}$ cells, $\mathrm{BD}=\mathrm{Bile}$ duct, $\mathrm{CV}=\mathrm{Central}$ vein, $\mathrm{PV}=$ Portal vein

combined effect of hyperglycemia, dyslipidemia along with oxidative stress and inflammation, in turn, induce cellular apoptosis (programmed cell death), even necrosis. ${ }^{18,19}$ The extract possessing potent antioxidant action significantly inhibited membrane damage, produced by lipid peroxides and also induced cellular antioxidants. These hepatocellular damages were restored near normal by treatments with hydro-alcoholic extract of Rhizophora mucronata.

Type 2 diabetes mellitus is a non-insulin dependent chronic diabetic state, which mainly develops due to insulin-resistance condition. Several surrogate markers are developed in order to quantify insulin resistance. The homeostasis model assessment (HOMA) proposed by Matthews in 1985, is a validated mathematical tool for predicting insulin resistance from blood glucose and insulin level and has being widely used regularly in clinical and epidemiological studies. ${ }^{16}$ Research revealed the significant anti-diabetic action of the hydro-alcoholic extract of Rhizophora mucronata leaves in STZ-NA induced type 2 diabetic rats. ${ }^{8,9}$ Present study reported that HOMA-IR was significantly high in the diabetic rats than the normal rats i.e. significant insulin resistance prevailed in the STZ-NA induced diabetic rats. RME showed marked reduction in insulin resistant parameters than the diabetic control rats. It also maintained the serum insulin and C-peptide levels like normal rats, in contrast with a slight deficiency in the diabetic controls, thereby indicating its insulin-mimetic action.

The activation of the pro-inflammatory cytokines like TNF- $\alpha$, IL- $1 \beta$ and IL- 6 plays a vital role in insulin signaling pathway. These all eventually lead to insulin resistance and glucose concentration in bloodstream increases due to the inability of the glucose molecules 
to enter the cell, developing hyperglycemia. ${ }^{20}$ Present study data showed that Rhizophora mucronata leaves significantly suppressed the pro-inflammatory cytokines in the serum, which were evidently increased in the diabetic rats. The correlation analysis also suggested that increased generation of the pro-inflammatory cytokine TNF- $\alpha$ is directly associated with the development of insulin resistance. Therefore, the extract showing antidiabetic action might be regulated through the inhibition of inflammatory response and thus preventing insulin resistance. Another mangrove plant Rhizophora mangle bark extract also displayed hepatoprotective effect along with the improvement of insulin resistance and beneficial effects on tissue inflammation. ${ }^{21}$ Therefore, the present study revealed that treatment with hydroalcoholic extract of Rhirophora mucronata leaves (RME) portrays hepatoprotective effect in diabetic rats with significant reduction in inflammatory cytokines and the insulin resistance index along with its beneficial antihyperglycemic effect in experimentally induced type 2 diabetic rats.

\section{CONCLUSION}

Present study results indicated that the anti-diabetic action of the hydro-alcoholic extract of the mangrove plant Rhirophora mucronata might be mediated through significant antioxidant action with reduction of inflammatory cytokines as well as amelioration of insulin resistance. It reduced the cellular oxidative stress and potentiated cellular antioxidant enzymes, providing beneficial action in protecting the liver from diabetes induced damage. This might be also a great advantage in maintaining normal glucose homeostasis and preventing diabetes associated complications.

\section{ACKNOWLEDGEMENT}

The authors would like to express gratitude to the Department of Pharmacology, R. G. Kar Medical College, Kolkata for providing the platform to conduct the study. Authors also acknowledge academic support from West Bengal University of Health Sciences, Kolkata in this research.

\section{CONFLICT OF INTEREST}

The Authors declare no conflict of interest.

\section{ABBREVIATIONS}

T2DM: Type 2 Diabetes Mellitus; RME: Hydroalcoholic extract of Rhizophora mucronata leaves; HOMA: Homeostasis model assessment; TNF- $\alpha$ :
Tumour necrosis factor- $\alpha$; IL-6: Interleukin-6; IL-1 $\beta$ : Interleukin-1 $\beta$; STZ: Streptozotocin; NA: Nicotinamide; SGOT: Serum glutamic oxaloacetic transaminase; SGPT: Serum glutamic pyruvic transaminase; ALP: Alkaline phosphatase; NO: Nitric oxide; LPO: Lipid peroxidation; GSH: Reduced glutathione; SOD: Superoxide dismutase; MDA: Malondialdehyde; TCA: Tri-chloro acetic acid; TBA: Thiobarbituric acid; HCl: Hydrochloric acid; PMS: Phenazonium methosulphate; NBT: Nitroblue tetrazolium; NADH: Nicotinamide adenine dinucleotide reduced; EDTA: Ethylene di-amine tetra acetic acid; ELISA: Enzyme-linked immunosorbent assay; FBS: Fasting blood sugar; SEM: Standard error of mean; CPCSEA: Committee for the Purpose of Control and Supervision of Experiments on Animals.

\section{REFERENCES}

1. Adeva-Andany M, Pérez-Felpete N, Fernández-Fernández C, DonapetryGarcía C, Pazos-García C. Liver glucose metabolism in humans. Bioscience Reports. 2016;36(6):e00416.

2. Dal S, Jeandidier N, Seyfritz E, Bietiger W, Péronet C, Moreau F, et al. Featured Article: Oxidative stress status and liver tissue defenses in diabetic rats during intensive subcutaneous insulin therapy. Experimental Biology and Medicine. 2015;241(2):184-92.

3. Keane K, Cruzat V, Carlessi R, DeBittencourt P, Newsholme P. Molecular Events Linking Oxidative Stress and Inflammation to Insulin Resistance and $\beta$-Cell Dysfunction. Oxidative Medicine and Cellular Longevity. 2015;2015:115.

4. Houstis N, Rosen E, Lander E. Reactive oxygen species have a causal role in multiple forms of insulin resistance. Nature. 2006;440(7086):944-8.

5. Palsamy $P$, Sivakumar $S$, Subramanian $S$. Resveratrol attenuates hyperglycemia-mediated oxidative stress, proinflammatory cytokines and protects hepatocytes ultrastructure in streptozotocin-nicotinamide-induced experimental diabetic rats. Chemico-Biological Interactions. 2010;186(2):20010.

6. Nasri H, Shirzad H, Baradaran A, Rafieian-Kopaei M. Antioxidant plants and diabetes mellitus. Journal of Research in Medical Sciences. 2015;20(5):491502.

7. Nour A, Nitthiya J, Omer MS. The Potential of Rhizophora mucronata in Extracting the Chemical Composition and Biological Activities as Mangrove Plants: A Review. Australian Journal of Basic and Applied Sciences. 2016;10(4):114-39.

8. Pandey A, Gupta P, Lal V. Hypoglycemic effect of Rhizophora mucronata in streptozotocin induced diabetic rats. Journal of Complementary and Integrative Medicine. 2014;11(3):179-83.

9. Adhikari A, Ray M, Sur T, Biswas S, Roy R, Hazra A, et al. Anti-Diabetic Activity of Rhizophora mucronata Leaves in Streptozotocin-Nicotinamide Induced Animal Model. The Journal of Middle East and North Africa Sciences. 2018;4(8):1-7.

10. Berenguer B, Sánchez L, Quílez A, López-Barreiro M, DeHaro O, Gálvez J, et al. Protective and antioxidant effects of Rhizophora mangle L. against NSAIDinduced gastric ulcers. Journal of Ethnopharmacology. 2006;103(2):194-200.

11. Oyedemi S, Bradley G, Afolayan A. Antidiabetic Activities of Aqueous Stem Bark Extract of Strychnos henningsii Gilg in Streptozotocin-nicotinamide Type 2 Diabetic Rats. Iranian Journal of Pharmaceutical Research. 2012;11(1):2218.

12. Ahangarpour A, Zamaneh HT, Jabari A, Nia HM, Heidari H. Antidiabetic and hypolipidemic effects of Dorema aucheri hydroalcoholic leave extract in streptozotocin-nicotinamide induced type 2 diabetes in male rats. Iranian Journal of Basic Medical Sciences. 2014;17(10):808-14. 
13. Lowry $\mathrm{OH}$, Rosebrough NJ, Farr AL, Randall RJ. Protein measurement with the Folin phenol reagent. The Journal of Biological Chemistry. 1951;193(1):265-75

14. AISaid M, Mothana R, Raish M, Al-Sohaibani M, Al-Yahya M, Ahmad A, et al. Evaluation of the Effectiveness of Piper cubeba Extract in the Amelioration of CCl4-Induced Liver Injuries and Oxidative Damage in the Rodent Model. Bio Med Research International. 2014;2015:1-11.

15. Almonte-Flores D, Paniagua-Castro N, Escalona-Cardoso G, Rosales-Castro M. Pharmacological and Genotoxic Properties of Polyphenolic Extracts of Cedrela odorata L. and Juglans regia L. Barks in Rodents. Evidence-Based Complementary and Alternative Medicine. 2015;2015(2):1-8.

16. Matthews D, Hosker J, Rudenski A, Naylor B, Treacher D, Turner R. Homeostasis model assessment: Insulin resistance and beta-cell function from fasting plasma glucose and insulin concentrations in man. Diabetologia. 1985;28(7):412-9.

17. Rahman M, Siddiqui M, Jamil K. Effects of Vepacide (Azadirachta indica) on asp artate and al anine aminotransferase profiles in a subchronic study with rats. Human and Experimental Toxicology. 2001;20(5):243-9.
18

Francés D, Ingaramo P, Ronco M, Carnovale C. Diabetes, an inflammatory process: Oxidative Stress and TNF-alpha involved in hepatic complication. Journal of Biomedical Science and Engineering. 2013;06(06):645-53.

19. Mohamed J, Nazratun NAH, Zariyantey AH, Budin SB. Mechanisms of Diabetes-Induced Liver Damage: The role of oxidative stress and inflammation. Sultan Qaboos University Medical Journal. 2016;16(2):e13241.

20. Balbaa M, El-Zeftawy M, Ghareeb D, Taha N, Mandour A. Nigella sativa relieves the Altered Insulin Receptor Signaling in Streptozotocin-Induced Diabetic Rats Fed with a High-Fat Diet. Oxidative Medicine and Cellular Longevity. 2016;2016:1-16.

21. DeSouza ML, Caria C, Santos P, Ruy C, DaSilva LN, Moreira D, et al. Modulatory Effect of Polyphenolic Compounds from the Mangrove Tree Rhizophora mangle L. on Non-Alcoholic Fatty Liver Disease and Insulin Resistance in High-Fat Diet Obese Mice. Molecules. 2018;23(9):2114.

\section{PICTORIAL ABSTRACT}

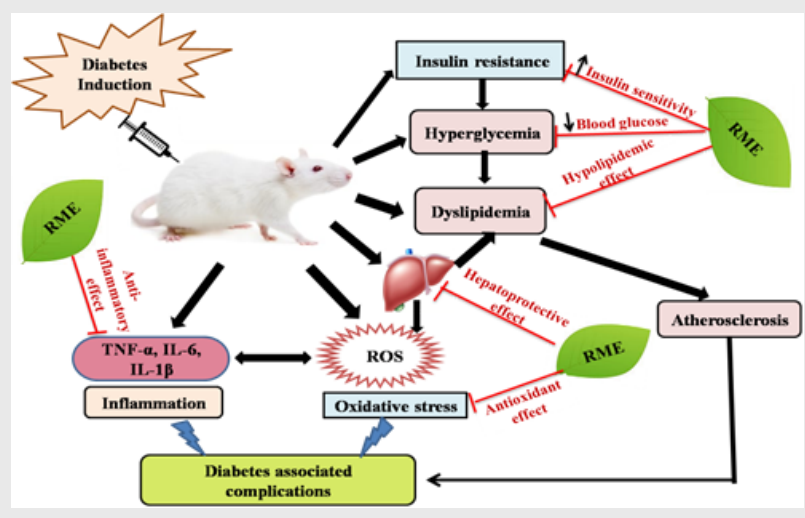

\section{About Authors}

Dr. Moumita Ray: Assistant Professor, Department of Pharmaceutical Technology, JIS University, Kolkata.

Dr. Rania Indu: PhD, Department of Pharmacology, R. G. Kar Medical College, Kolkata.

Dr. Sangita Bhattacharya: PhD, Department of Pharmacology, R. G. Kar Medical College, Kolkata.

Prof.(Dr.) Anjan Adhikari: Professor \& Head, Department of Pharmacology, Coochbehar Government Medical College, Coochbehar.

\section{SUMMARY}

Present study revealed the potential anti-hyperglycemic property with lipid-lowering action of the hydro-alcoholic extract of Sundarban mangrove Rhizophora mucronata Lam. leaves. The hypoglycemic potential of the mangrove leaf extract in type 2 diabetic model might be attributed to the insulin potentiating action and protection against insulin resistance. The leaves consist of antioxidative phytochemicals, secondary metabolites like phenolic, tannin and flavonoids. RME was found to possess significant antioxidant, anti-inflammatory properties and subsequently ameliorated the liver damages in diabetic state, leading to an overall improvement in homeostasis. The extract significantly suppressed the expression of pro-inflammatory cytokines like TNF- $\alpha$, IL- $1 \beta$ and IL- 6 . This inhibition of inflammatory response might augment the insulin sensitivity in diabetic condition. Evaluating the whole study, it may be proposed that a single bioactive compound or a group of bioactive compounds present in Rhizophora mucronata Lam leaves may be responsible for exerting a holistic perspective behind its potential medicinal action. Rhizophora mucronata, being a mangrove, is rich in antioxidant compounds to withstand the environmental stress. Presence of these compounds can contribute to the anti-diabetic potential of this leaves by preventing diabetes-induced inflammation and oxidative stress.

Cite this article: Ray M, Indu R, Bhattacharya S, Adhikari A. Protective Effect of Rhizophora mucronata Leaves on Hepatic Oxidative Stress, Serum Cytokines and Insulin Resistance in Type 2 Diabetic Rats. Indian J of Pharmaceutical Education and Research. 2020;54(3s):s562-s569. 